\title{
SPLEEN CELL PROLIFERATION DURING AND AFTER SKIN MYIASIS BY HUMAN BOT FLY Dermatobia hominis
}

\author{
Jomara Mendes GONÇALVES(1), Maria Fernanda Alves do NASCIMENTO(1), Natália Martins BREYNER(2), Viviane Cristina FERNANDES(2), \\ Alfredo Miranda de GÓES(2) \& Antonio César Rios LEITE(1)
}

\begin{abstract}
SUMMARY
Spleen cells from mice were examined at 5, 10, 15, 20 and 25 days post-infection (dpi) with Dermatobia hominis larva and at 5, $10,15,30$ and 60 days post-larval emergence (dple). Cell proliferation in vitro assays were carried out with RPMI-1640 medium and larval secretory product (LSP) of D. hominis at 5, 10, 15, 20 and 25 days. When each group of mice was tested against each medium, significance was only seen for $25 \mathrm{dpi}$, with increasing order: LSP-10 d, -25 d, -5 d, -20 d, -15 d and RPMI. Significant results were also observed when each medium was tested against mice at each dpi or dple. Each dple group vs. each medium produced significant results only for $10 \mathrm{dple}$, with increasing order: LSP-5 d, -20 d, -25 d, -10 d, -15 d and RPMI. Comparative tests were also carried out between groups to refine certain observations. The LSPs were also analyzed using SDS-PAGE. The results prove that myiasis caused depletion of spleen cells, particularly under the effect of the LSP-10 and -15, but the cells tended to increase up to 60 dple. This in vitro assay may represent the real systemic immune response in the relationship LSP-D. hominis-host.
\end{abstract}

KEYWORDS: Dermatobia hominis; Mice; Skin myiasis; Spleen cell; Blastogenesis.

\section{INTRODUCTION}

Cutaneous obligatory myiasis by the human bot fly Dermatobia hominis (L. Jr.) larva is a Neotropical zoonotic disease that produces severe economic losses to livestock production and also has public health importance ${ }^{11}$. The developmental cycle of $D$. hominis is unusual in that adults are aphagous, mated females capturing and depositing their eggs on several species of flies, including Musca domestica and Stomoxys calcitrans. After about a week, when the phoretic host feeds or lands on a mammalian host, the bot fly larvae hatch and immediately penetrate the animal's skin. Although the pathological and immunological aspects of human bot fly myiasis have been little studied under field conditions $^{6,26}$, mice have proved to be a suitable laboratory model for the relationship between $D$. hominis and its hosts ${ }^{5,13,18,21}$. The response of mouse spleen cells during and after infection by larvae of $D$. hominis is described here.

\section{MATERIAL AND METHODS}

Animal infection: Each animal from 10 groups of six male Swiss mice $(20-25 \mathrm{~g})$ was submitted to skin infection with one newly hatched larva of $D$. hominis reared in our laboratory ${ }^{9}$. The mice were sacrificed and spleens obtained from groups 1-5 at 5, 10, 15, 20 and 25 days-postinfection (dpi), respectively. Spleens from groups 6-10 were collected at 5, 10, 15, 30 and 60 days post-larval-emergence (dple) respectively.
Spleens from corresponding negative control $11^{\text {th }}$ group (without infection $=0 \mathrm{dpi}$ ) were also examined.

Larval secretory product (LSP): Five groups with five male adult Wistar rats (190-220g) were infested with four newly hatched larvae of D. hominis and sacrificed at 5, 10, 15, 20 and 25 dpi to collect the larvae from the skin tissues ${ }^{9}$. Larvae at each infested date were washed three times with RPMI-1640 medium (Sigma) and conditioned in Falcon tubes with $2 \mathrm{~mL}$ of RPMI for incubation at $37^{\circ} \mathrm{C}$ in a $5 \% \mathrm{CO}_{2}$ atmosphere for $24 \mathrm{~h}$. Crude D. hominis LSP was obtained at $5 \mathrm{~d}$ (LSP-5d) from 30 first larvae $\left(\mathrm{L}_{1}\right)$; at $10 \mathrm{~d}$ (LSP-10 d) or $15 \mathrm{~d}$ (LSP-15 d) from 15 second larvae $\left(\mathrm{L}_{2}\right)$ and at $20 \mathrm{~d}$ (LSP-20 d) or $25 \mathrm{~d}$ (LSP-25 d) from 10 third larvae $\left(\mathrm{L}_{3}\right)$. The LSP of each different days or larval instars was stored in liquid nitrogen until ready for use.

Concentration and electrophoreses of LSP: Protein concentration of the LSP was determined using the Bradford (1976) technique and subjected to continuous electrophoresis using $10 \%$ SDS polyacrylamide gels, under reducing conditions ${ }^{14}$. The protein concentration used to electrophoresis was of $50 \mu \mathrm{g} / \mathrm{LPG} \mu \mathrm{L}$. The separated proteins were stained with Coomassie blue.

In vitro spleen proliferation response: Spleens of each group (1-11) rats were washed three times with RPMI, macerated, immersed in 20 $\mathrm{mL}$ RPMI, filtered and the filtrate centrifuged at $1400 \mathrm{RPM}$ for $10 \mathrm{~min}$. 
GONÇALVES, J.M.; NASCIMENTO, M.F.A.; BREYNER, N.M.; FERNANDES, V.C.; GÓES, A.M. \& LEITE, A.C.R. - Spleen cell proliferation during and after skin myiasis by human bot fly Dermatobia hominis. Rev. Inst. Med. trop. S. Paulo, 51(3): 149-154, 2009.

Erythrocytes were lysed by re-suspending the pellet in $300 \mu \mathrm{L}$ Trisammonium chlorite plus $30 \mathrm{~mL}$ MEM (minimum essential medium eagle, Sigma) and washing with the same solution. The spleen cells were suspended in $20 \mathrm{~mL}$ of RPMI, diluted in $10 \mathrm{~mL}$ Tweck solution and counted under a Neubauer camera. Cell proliferation assays (in triplicate) were done in response to RPMI and LSP at 5 d, 10 d, 15 d, 20 $\mathrm{d}$ and $25 \mathrm{~d}$. Spleen cells $\left(1 \times 10^{6}\right)$ were cultured in $200 \mu \mathrm{L}$ culture medium in 96-well flat-bottom plates. Except for the control group, $25 \mu \mathrm{g} / \mathrm{mL}$ of LSP was introduced in the culture medium in each plate and incubated at $37^{\circ} \mathrm{C}$ in a $\mathrm{CO}_{2}$ incubator for $5 \mathrm{~d}$. At $18 \mathrm{~h}$ before the final incubation, $0.5 \mu \mathrm{Ci}$ of titrated thymidine (specific activity, $37 \mathrm{Ci} / \mathrm{mL}$; New England Nuclear, Boston, MA, USA) was added to each well. Cells were harvested onto glass fiber paper and the incorporated radioactivity was measured by a liquid scintillation $\beta$-counter. The results were expressed as mean \pm S.E. of c.p.m. values.

Statistical analyses: The results of the blastogenesis were analyzed by non-parametric methods (GraphicPad Prism 4.03 software) by comparison among all groups (Kruskal-Wallis test) and between pairs of groups (Mann-Whitney U test) using independent variables. The data are represented in box and whisker plots, the middle line corresponding to the median and the lower and upper line representing the 25 and 75 percentiles, respectively (50\% of the data fall within the box, and $25 \%$ each above the below). The whiskers above and below the box plot indicate $95 \%$ and $5 \%$ percentiles, respectively. Values were considered significant at $p<0.05$.

\section{RESULTS}

Animal infection: The $\mathrm{L}_{1}$ of $D$. hominis changed to $\mathrm{L}_{2}$ at six dpi, the $\mathrm{L}_{3}$ moulted at $16 \mathrm{dpi}$ and the mature warbles escaped from the host around $30 \mathrm{dpi}$. A scar formed on the skin of each mouse 7-10 days later. In the laboratory $\mathrm{L}_{3}$ left the experimentally infested mice and pupated, resulting in fertile adult $D$. hominis.

In vitro spleen cell proliferation from infested mice: When the response of each group (1-5) with each substrate was analyzed, significance was only seen at 25 days of infection (group 5) increasing as follows: LSP-10 d, $-25 \mathrm{~d},-5 \mathrm{~d},-20 \mathrm{~d},-15 \mathrm{~d}$ and RPMI (Fig. 1). In the reciprocal analysis, i.e., of each substrate with each mouse group, significance was observed in all assays, highest values being seen for RPMI (Fig. 2): 25, 5, 20, 10, 15 dpi and control; LSP-5 d (Fig. 3): 25, 5, 10, 20, 15 dpi and control; LSP-10 d (Fig. 4): 25, 10, 5, 20, 15 dpi and control; LSP-15 d (Fig. 5): 25, 5, 10, 20, 15 dpi and control; LSP-20 d (Fig. 6): 25, 10, 5, 15 dpi, control and 20 dpi; LSP-25 d (Fig. 7): 25, 10 dpi, control, 5, 20 and 15 dpi. The results of between-group analyses (Mann-Whitney U test) are summarized in Table 1.

In vitro spleen cell proliferation from mice at days-post-larvalemergence: Analyses of each mouse group $v s$ each medium were only significant for 10 dple, values increasing in the following order: LSP-5 d, -20 d, -25 d, -10 d, -15 d and RPMI. Significant results were only obtained for three assays, when each medium was analyzed with each mouse group, values increasing as follows: to RPMI: 30, 10, 15, 60, 5 dple and control; LSP-10 d: 30, 10, 15, 5, 60 dple and control and LSP$15 \mathrm{~d}$ : $30,10,15$ dple, control, 5 and 60 dple. Additional test results are also shown in Table 2.
Concentration and electrophoreses of LSP: Separation of LSP molecules by SDS-PAGE revealed multiple protein bands (Fig. 8), their molecular weights ranging from $12-50 \mathrm{kDa}$. Major stained protein bands of $12-25 \mathrm{kDa}$ were seen in all larval stages.

\section{DISCUSSION}

The metamorphosis of D. hominis inside mammalian skin occurs below the point of $\mathrm{L}_{1}$ penetration, in deep dermis ${ }^{21}$. This contrasts with other oestrid species, e.g. rodent bot fly (Cuterebra) and cattle bot fly (Hypoderma) where the $\mathrm{L}_{1}$ migrate within the host skin before the second and third instars fix in the cutaneous tissues to form the mature warble $\mathrm{e}^{16,24,25}$. The multi-host parasitism exhibited by $D$. hominis also differs from the host specificity seen in other bot flies. There is usually a balance between the host and the three larval stages ${ }^{6}$. Preliminary studies

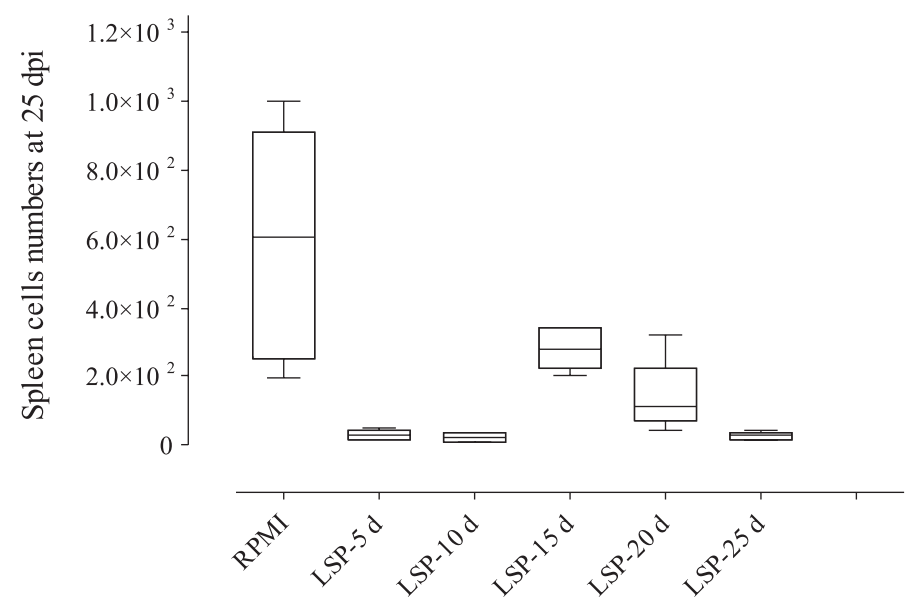

Culture medium

Fig. 1 - Box and whisker plots representing the numbers of spleen cells from mice at 25 days post-infection (dpi) by Dermatobia hominis submitted to RPMI and larval-secretoryproduct (LSP).

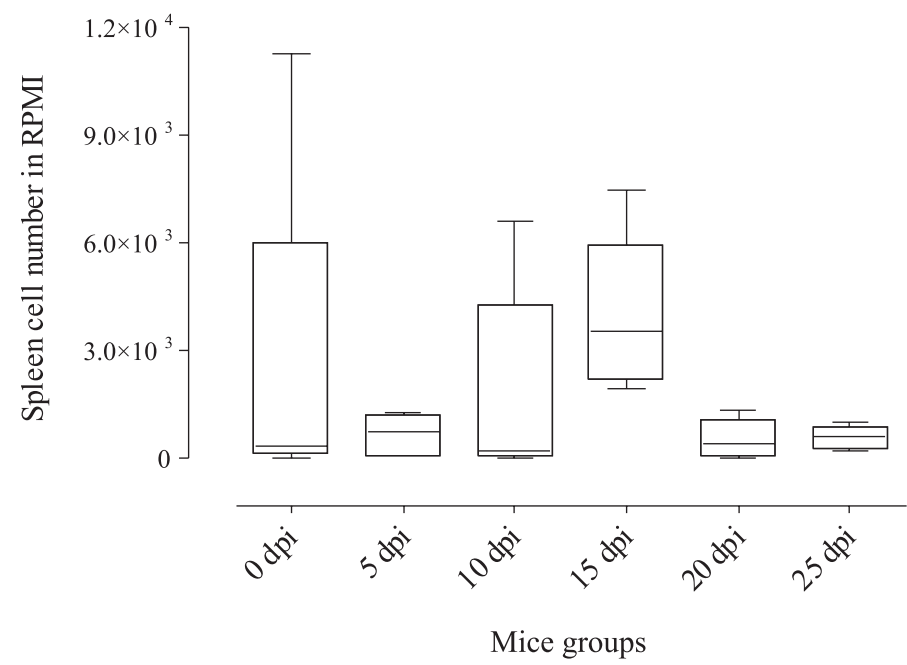

Fig. 2 - Box and whisker plots representing the numbers of spleen cells from mice control and at days post-infection (dpi) by Dermatobia hominis submitted to RPMI. 


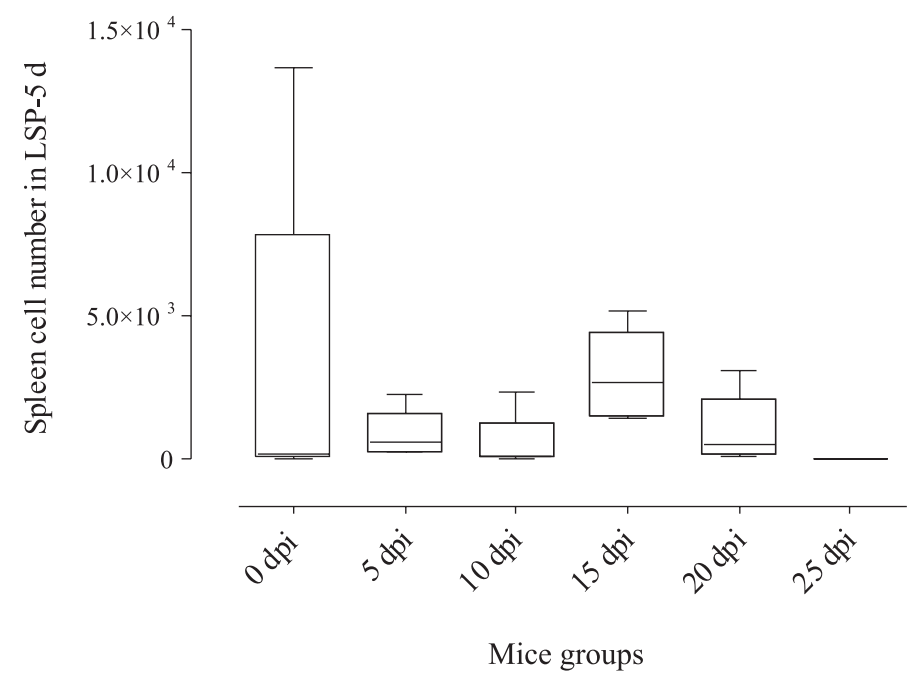

Fig. 3 - Box and whisker plots representing the numbers of spleen cells from mice control and at days post-infection (dpi) by Dermatobia hominis submitted to larval-secretory-product (LSP) at five days.

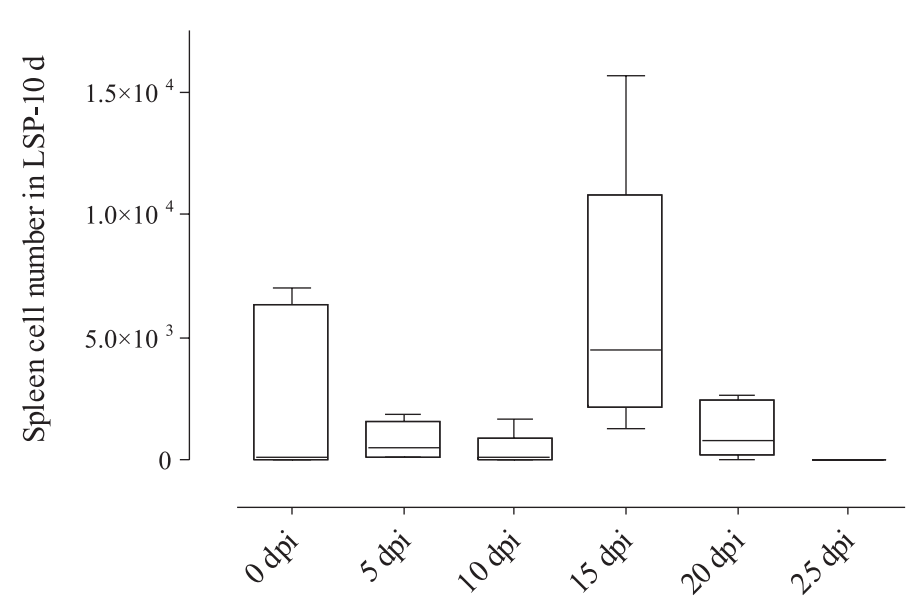

Mice groups

Fig. 4 - Box and whisker plots representing the numbers of spleen cells from mice control and at days post-infection (dpi) by Dermatobia hominis submitted to larval-secretory-product (LSP) at 10 days.

have demonstrated that bot burden, instar type, infection or re-infection can regulate the host's inflammatory process as well as its humoral and cellular immune responses ${ }^{4,6,7,17,20}$.

As soon as D. hominis $\mathrm{L}_{1}$ invades the host's skin, cellular and molecular changes occur in response to the mechanical presence of the larval stage as well as its secretory products. A chronological recruitment of the cells to skin lesions has been studied during and after infection in rats ${ }^{21,22}$. Cellular or humoral responses against human bot fly myiasis using rabbits, cattle and mice were recently re-examined ${ }^{17}$. However, cytological tissue changes (or damage) in warble-infested skin has been poorly studied under natural or controlled conditions. Circulating leucocytes in hosts with $D$. hominis myiasis are reported in cattle ${ }^{1,8}$ and

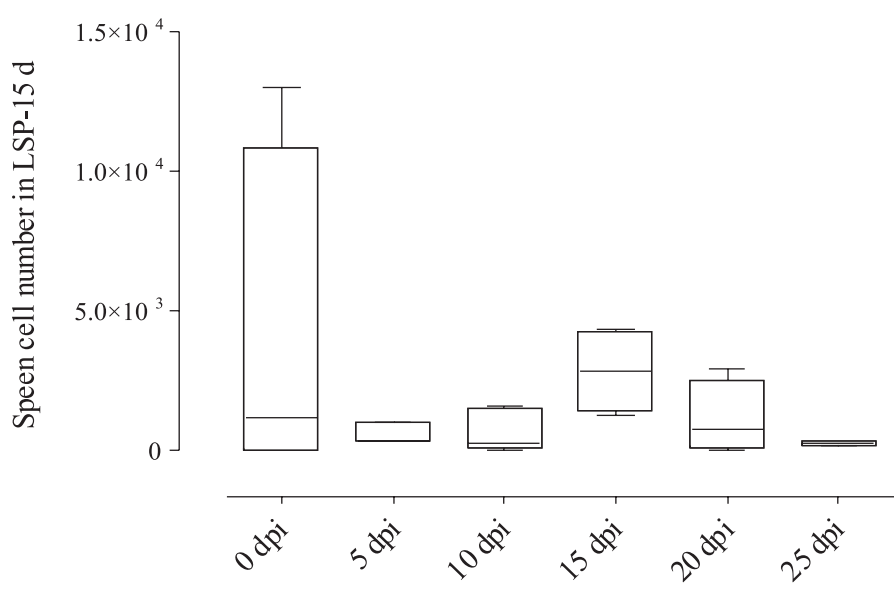

Mice groups

Fig. 5 - Box and whisker plots representing the numbers of spleen cells from mice at days post-infection (dpi) by Dermatobia hominis submitted to larval-secretory-product (LSP) at 15 days (by Kruskal-Wallis test)

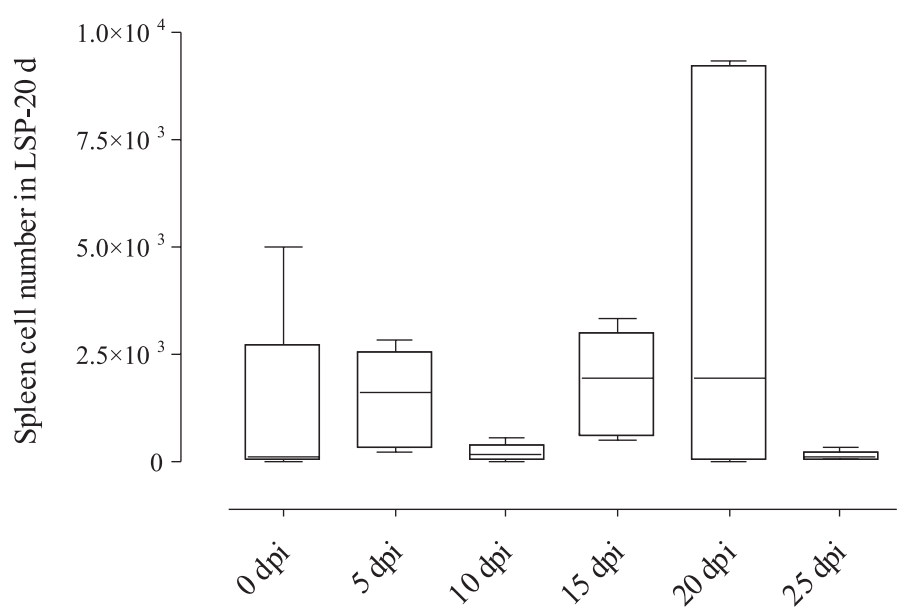

\section{Mice groups}

Fig. 6 - Box and whisker plots representing the numbers of spleen cells from mice at days post-infection (dpi) by Dermatobia hominis submitted to larval-secretory-product (LSP) at 20 days.

rats $^{10}$. Except for observations of alterations in response to migration of the $\mathrm{L}_{1}$ of Cuterebra and Hypoderma, there have been few studies of the host cellular pathways in skin myiasis ${ }^{6,26}$.

Oestrid LSP has been most studied in $H$. lineaum $\mathrm{L}_{1}$ midgut, from which enzymes (hypodermins) with immune regulation properties were isolated. Both hypodermin (trypsins) $\mathrm{A}$ and $\mathrm{B}^{15,28}$ deplete complement cytolytic activity ${ }^{2,3}$, B also reducing leukocyte and lymphocyte blastogenesis, as well as the production of interleukin-2 and prostaglandin ${ }^{19}$. Although molecules from $D$. hominis LSP have not been identified, our results confirm that cellular suppression occurs in mice with human bot fly myiasis. Based on the results of studies using crude extracts of $D$. hominis $\mathrm{L}_{2}$ and $\mathrm{L}_{3}$, it has been suggested that serine- 


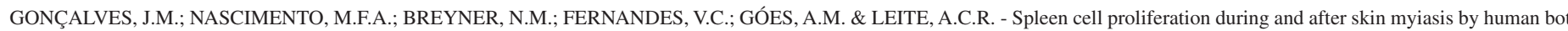
fly Dermatobia hominis. Rev. Inst. Med. trop. S. Paulo, 51(3): 149-154, 2009.

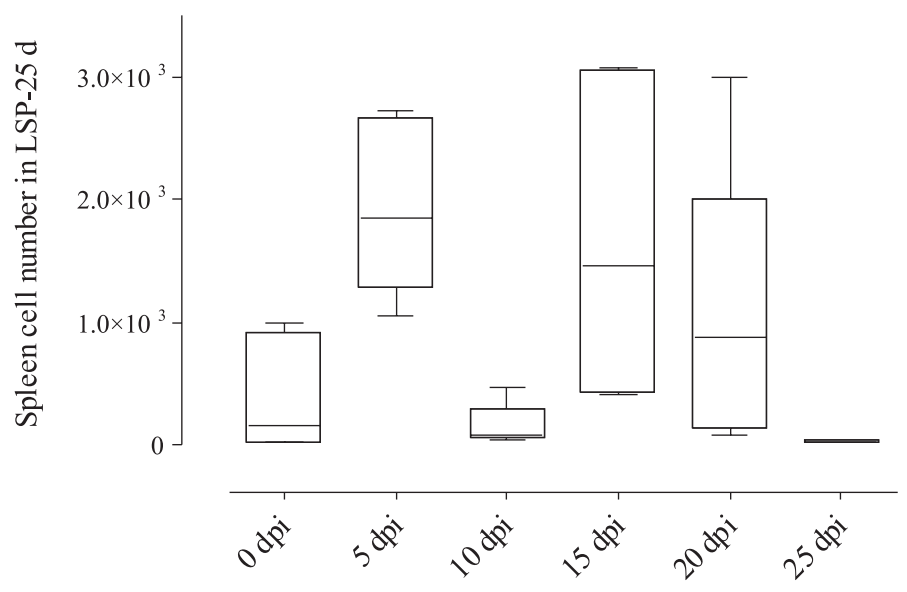

Mice groups

Fig. 7 - Box and whisker plots representing the numbers of spleen cells from mice at days post-infection (dpi) by Dermatobia hominis submitted to larval-secretory-product (LSP) at 25 days.

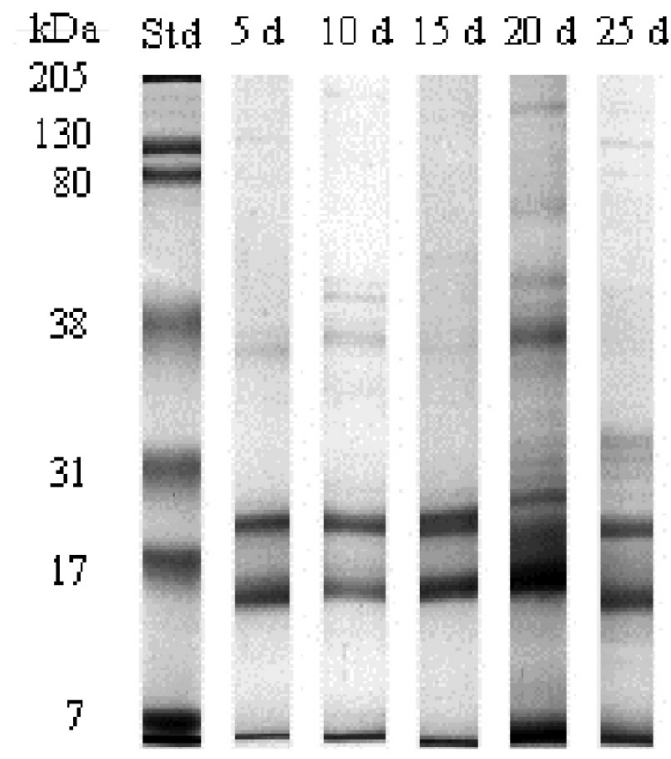

Fig. 8 - SDS-PAGE (10\%) of larval-secretory-product from Dermatobia hominis: at five days (first instar), 10 or 15 days (second instar) and 20 or 25 days (third instar).

proteases occur in such larvae ${ }^{23}$. Our data reveal a reduction in spleen cell numbers during $D$. hominis myiasis.

Assays with each dpi vs. each medium revealed that significant reductions only occurred at $25 \mathrm{dpi}$ and that RPMI and LSP-15d produced most cell proliferation, followed by LSP-20 d. The immunosuppressive effect of the larvae could be switched off at $15 \mathrm{~d}$, when the $L_{2}$ molts to $\mathrm{L}_{3}$. Based on the other analysis (U test), mice have more spleen cells at $15 \mathrm{dpi}$ on LSP-15d than on other media, and more on LSP-10 d than LSP-20 or $-25 \mathrm{~d}$. When the reciprocal tests were carried out, i.e. each
Table 1

Analyses of spleen cells from mice control and days-post-infestation (dpi) by Dermatobia hominis larvae in response to media (RPMI and larval secretory product $=\mathrm{LSP}$ ) of warbles at 5, 10, 15, 20 and 25 days and each medium vs each group

Assays $\quad$ Significant results by

Mann-Whitney U test

Mice control (0 dpi) vs medium No

Mice with 5 dpi vs each medium

Pro-25 dpi x RPMI, LSP-5 d, -10 $\mathrm{d}$ and $-15 \mathrm{~d}$

Mice with 10 dpi vs each medium No

Mice with 15 dpi vs each medium

Pro-LSP-10 d x LSP-20 d, -25 d

Mice with 20 dpi vs each medium No

Mice with 25 dpi vs each medium Pro-RPMI x LSP-5 d, -10 d, -20 $d$ and $-25 d$

Pro-LSP-15 d x LSP-5 d, $-10 \mathrm{~d}$, $-20 \mathrm{~d}$ and $-25 \mathrm{~d}$

Pro-LSP-20 d x LSP-5 d, -10 d and $-25 d$

RPMI $v s$ each mice group

LSP-5 d vs each mice group

LSP-10 d vs each mice group

LSP-15 d vs each mice group

LSP-20 d vs each mice group

LSP-25 d vs each mice group

Pro-15 dpi x 5 dpi, 10 dpi, 20 dpi and $25 \mathrm{dpi}$

Pro-control x 25 dpi

Pro-5 dpi x 25 dpi

Pro-10 dpi x 25 dpi

Pro-15 dpi x 5 dpi, 10 dpi, 20 dpi and $25 \mathrm{dpi}$

Pro-20 dpi x 25 dpi

Pro-control x 25 dpi

Pro-5 dpi x 25 dpi

Pro-10 dpi x 25 dpi

Pro-15 dpi x 5 dpi, 10 dpi, 20 dpi and $25 \mathrm{dpi}$

Pro-20 dpi x 25 dpi

Pro-5 dpi x 25 dpi

Pro-15 dpi x 5 dpi, 10 dpi and 25 dpi

Pro-5 dpi x 10 dpi and 25 dpi Pro-15 dpi x 10 dpi and $25 \mathrm{dpi}$

Pro-5 dpi x control, 10 dpi and 25 dpi

Pro-10 dpi x 25 dpi

Pro-15 dpi x control, 10 dpi and 25 dpi

Pro-20 dpi x 25 dpi

Pro $=$ favorable 


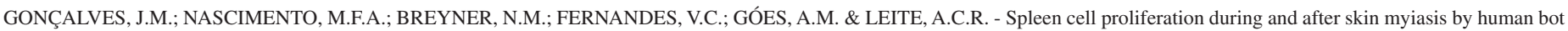
fly Dermatobia hominis. Rev. Inst. Med. trop. S. Paulo, 51(3): 149-154, 2009.

Table 2

Analyses of spleen cells from mice control and days-post-larval-emergence (dple) of Dermatobia hominis in response to media (RPMI and larval secretory product $=$ LSP) of warbles at 5, 10, 15, 20 and 25 days, and each medium versus each group

\begin{tabular}{|c|c|}
\hline Assays & $\begin{array}{l}\text { Significant results by } \\
\text { Mann-Whitney U test }\end{array}$ \\
\hline Mice with 5 dple vs each medium & No \\
\hline Mice with 10 dple vs each medium & $\begin{array}{l}\text { Pro-RPMI x } 5 \mathrm{~d}, 10 \mathrm{~d}, 20 \mathrm{~d} \text { and } \\
25 \mathrm{~d} \\
\text { Pro-10d x } 20 \mathrm{~d} \\
\text { Pro-15d x } 5 \mathrm{~d}, 10 \mathrm{~d}, 20 \mathrm{~d} \text { and } \\
25 \mathrm{~d}\end{array}$ \\
\hline Mice with 15 dple vs each medium & No \\
\hline Mice with 30 dple vs each medium & No \\
\hline Mice with 60 dple vs each medium & No \\
\hline RPMI vs each mice group & $\begin{array}{l}\text { Pro-5 dple x } 30 \text { dple } \\
\text { Pro-10 dple x } 30 \text { dple } \\
\text { Pro- } 15 \text { dple x } 30 \text { dple } \\
\text { Pro- } 60 \text { dple x } 10 \text { dple, } 15 \text { dple } \\
\text { and } 30 \text { dple }\end{array}$ \\
\hline LSP-5 d vs each mice group & Pro-60 dple x 30 dple \\
\hline LSP-10 d vs each mice group & $\begin{array}{l}\text { Pro-control } \\
\text { Pro-10 dple x } 30 \text { dple } \\
\text { Pro-60 dple x } 10 \text { dple, } 15 \text { dple } \\
\text { and } 30 \text { dple }\end{array}$ \\
\hline LSP-15 d vs each mice group & $\begin{array}{l}\text { Pro- } 10 \text { dple x } 30 \text { dple } \\
\text { Pro- } 60 \text { dple x control, } 5 \text { dple, } 15 \\
\text { dple, } 30 \text { dple }\end{array}$ \\
\hline LSP-20 d vs each mice group & $\begin{array}{l}\text { Pro-15 dple x } 10 \text { dple, } 30 \text { dple } \\
\text { Pro-60 dple x } 10 \text { dple, } 30 \text { dple }\end{array}$ \\
\hline LSP-25 d vs each mice group & $\begin{array}{l}\text { Pro-10 dple x } 30 \text { dple } \\
\text { Pro- } 60 \text { dple x } 10 \text { dple, } 15 \text { dple, } \\
30 \text { dple }\end{array}$ \\
\hline
\end{tabular}

Pro $=$ favorable

medium vs. each dpi, spleen cell suppression was also seen at the end of the infection. In this case more cells also found at $-15 \mathrm{dpi}$, indicating similar significance with RPMI, LSP-5d and -10 d (Table 2).

Among control and dple mice vs. each medium the unique significant result at 10 dple indicates that RPMI and LSP-15 d have similar effects on spleen cell numbers, producing more cells than all the other assays. Otherwise, irrespective of the medium used vs. dple the lowest cell numbers in mice occurred at 30 dple. However, at 60 dple mice usually have more cells than in other assays. If 60 dple mice are compared with control group (uninfested mice) there is equalization between them.
Based on SDS-PAGE, two marked bands of small peptides expressed in D. hominis LSP revealed the presence of homologous molecules in the three parasite instars. In contrast with $\mathrm{L}_{1}$ and $\mathrm{L}_{2}$, large amounts of peptides were observed in $\mathrm{L}_{3}$ at $20 \mathrm{~d}$ after infection. It is possible that at this point the $\mathrm{L}_{3}$ displays more LSP due to voracious parasitism. This is borne out by the results of histopathological studies ${ }^{21}$. The LSP of $D$. hominis may have similar peptides ( 23 and $18 \mathrm{kDa}$ ) to those described in O. ovis: $\mathrm{L}_{1}, \mathrm{~L}_{2}$ and $\mathrm{L}_{3}$ (larval extract), LSP and salivary gland of $\mathrm{L}_{3}{ }^{12}$. The warble fly $H$. lineatum (De Villers) has protease (trypsin-like) molecules which can break down bovine $\mathrm{C}_{3}{ }^{3}$. The peptide of approximately 38 $\mathrm{kDa}$ present in $\mathrm{L}_{2}$ and $\mathrm{L}_{3} O$. ovis ${ }^{27}$ may also be present in D. hominis. A spectrum of molecules from 60-97 kDa was detected in crude extract of D. hominis $\mathrm{L}_{2}$ and $\mathrm{L}_{3}^{8}$. Proteinases, probably serine-proteases of m.w. 13 and $22 \mathrm{kDa}$, were identified in crude extracts of $D$. hominis $\mathrm{L}_{2}$ and $\mathrm{L}_{3}$, and an unidentified molecule of $50 \mathrm{kDa}$ also seen in both instars ${ }^{23}$. Further studies of $D$. hominis LSP are in progress in our laboratory, which should provide new information on human bot fly myiasis.

\section{RESUMO}

\section{Proliferação de células do baço durante e após miíase por Dermatobia hominis}

Células do baço de camundongos foram examinadas aos 5, 10, 20 e 25 dias pós-infecção (dpi) com Dermatobia hominis e examinadas aos $5,10,15,30$ e 60 dias pós-emergência da larva (dpel). As células foram cultivadas em meio RPMI-1640 contendo, ou não (controle), produtos de secreção das larvas (PSL) de D. hominis com idade de 5, 10, 15, 20 e 25 dias. Em cada grupo com cinco camundongos testados nos meios de cultura, o número de células foi significativo para $25 \mathrm{dpi}$, com crescente aumento na seguinte ordem: PSL-10 d, -25 d, -5 d, -20 d, -15 d e RPMI. Resultados significantes foram também observados nos testes entre cada meio contendo células tanto de camundongos dpi ou dpel. Em cada dpel grupo versus meio significância foi somente verificada para 10 dpel, na ordem crescente: PSL-5 d, -20 d, -25 d, -10 d, -15 d e RPMI. Testes comparativos foram também realizados entre grupos. O PSL foi analisado sob SDS-PAGE. Os resultados provam que a miíase causou depleção de células do baço, particularmente sob efeito do PSL-10 e -15, mas ocorreu normalidade do número de células aos 60 dpel. Este ensaio in vitro pode representar uma resposta imune sistêmica na relação PSL- $D$. hominis-hospedeiro.

\section{ACKNOWLEDGMENTS}

Thanks to Dr Bruce Alexander for revision of this manuscript.

\section{REFERENCES}

1. BARbOSA, C.G.; SANAVRIA, A. \& BARBOSA, D.P.R.C. - Alterações hematológicas em bovinos infestados experimentalmente com larvas de Dermatobia hominis (Diptera: Cuterebridae). Rev. bras. Parasit. vet., 12: 61-67, 2003.

2. BOULARD, C. \& BENCHARIF, F. - Changes in the haemolytic activity of bovine serum complement by Hypoderma lineatum (insect oestridae) larval proteinases in naïve and immune cattle. Paras. Immunol., 6: 459-467, 1984.

3. BOULARD, C. - Degradation of bovine C3 by serine proteases from parasites Hypoderma lineatum (Diptera, Oestridae). Vet. Immunol. Immunopath., 20: 387 398, 1989. 
GONÇALVES, J.M.; NASCIMENTO, M.F.A.; BREYNER, N.M.; FERNANDES, V.C.; GÓES, A.M. \& LEITE, A.C.R. - Spleen cell proliferation during and after skin myiasis by human bot fly Dermatobia hominis. Rev. Inst. Med. trop. S. Paulo, 51(3): 149-154, 2009.

4. BOULARD, C. - Larval-host parasite relationships. Part A: Hypodermatinae hostparasite interactions. In: COLWELL, D.D.; HALL, M.J.R. \& SCHOLL, P.J. The Oestrid flies: biology, host-parasite relationships, impact and management. Oxfordshire, CAB International, 2006. p. 167-179.

5. CHAIA, G.; BORJA, G.E.; CHIARI, L.; SANTOS, C.N. \& ABREU, T.L. Experimental chemotherapy of dermatobiosis in laboratory animals. Rev. Inst. Med. trop. S. Paulo, 17: 298-306, 1975.

6. COLWELL, D.D.; HALL, M.J.R. \& SHOLL, P.J. - The Oestrid flies: biology, hostparasite relationships, impact and management. Oxfordshire, CAB International, 2006.

7. DORCHIES, P.; TABOURET, G.; HOSTE, H. \& JACQUIET, P. - Larval-host parasite relationships. Part D: Oestrinae host-parasite interactions. In: COLWELL, D.D.; HALL, M.J.R. \& SCHOLL, P.J. The Oestrid flies: biology, host-parasite relationships, impact and management. Oxfordshire, CAB International, 2006. p. 191-200.

8. FERNANDES, N.L.M.; SOCOL, V.T.; PINTO, S.B.; MINOZZO, J.C \& OLIVEIRA, C.A.L. - Resposta imuno-humoral e celular em bovinos da raça nelore imunizados com extratos de larvas (L2 e L3) de Dermatobia hominis (Linnaeus Jr., 1781). Cienc. rural, 37: 789-795, 2007.

9. FILIPPIS, T. \& LEITE, A.C.R. - Morphology of the second- and third-instar larvae of Dermatobia hominis by scanning electro microscopy. Med. vet. Entomol., 12: 160-168, 1998 .

10. GONÇALVES, J.M.; PEREIRA, M.C.T.; EVANGELISTA, L.G. \& LEITE, A.C.R. Expression of circulating leucocytes before, during and after myiasis by Dermatobia hominis in experimental infested rat. Rev. Inst. Med. trop. S. Paulo, 49: 289-292, 2007.

11. GUIMARÃES, J.H. \& PAPAVERO, N. - Myiasis caused by obligatory parasites. VI. Dermatobia hominis (Linnaeus Jr.) (Cuterebridae). In: GUIMARÃES, J.H. \& PAPAVERO, N. Myiasis in man and animals in the Neotropical region. São Paulo, Plêide, 1999. p. 257-302.

12. INNOCENTI, L.; MASETTI, M.; MACCHIONI, G. \& GIORGI, F. - Larval salivary gland proteins of the sheep nasal bot fly, (Oestrus ovis L.), are major immunogens in infested sheep. Vet. Parasit., 60: 273-282, 1995.

13. JOBSEN, J.A. \& MOURIER, H. - The morphology of the larval instars and pupa of Dermatobia hominis (Diptera: Cuterebridae). Entomol. Berich, 32: 218-224, 1972.

14. LAEMMLI, U.K. - Cleavage of structural proteins during the assembly of the head of bacteriophage T4. Nature, 227: 680-685, 1970.

15. LECROISEY, A.; TONG, N.T. \& KEIL, B. -Hypodermin B, a trypsin-related enzyme from the insect Hypoderma lineatum. Comparison with Hypodermin A and Hypoderma collagenase, two serine proteinases from the same source. Europ. J. Biochem., 134: 261-267, 1983.
16. LEITE A.C.R. \& WILLIAMS, P. - Experimental infection of rodents with larvae of Metacuterebra apicalis, a neotropical cuterebrid. Rev. bras. Parasit. vet., 8: 35-39, 1999.

17. LELLO, E. - Larval-host parasite relationships. Part B: Cuterebrinae host-parasite interactions. In: COLWELL, D.D.; HALL, M.J.R. \& SCHOLL, P.J. The Oestrid flies: biology, host-parasite relationships, impact and management. Oxfordshire, CAB International, 2006. p. 179-189.

18. LELLO, E. \& ROSIS, A.M.B. - Inflammatory reaction to the human bot-fly, Dermatobia hominis, in infested and reinfested mice. Med. vet. Entomol., 17: 55-60, 2003.

19. NICOLAS-GAULARD, I.; MOIRE, N. \& BOULARD, C. - Effect of the parasite enzyme, hypodermin A, on bovine lymphocyte proliferation and interleukin-2 production via the prostaglandin pathway. Immunology, 85: 160-165, 1995.

20. OTRANTO, D. - The immunology of myiasis: parasite survival and host defense strategies. Trends Parasit., 17: 176-182, 2001.

21. PEREIRA, M.C.T.; LEITE, V.H.R. \& LEITE, A.C.R. - Experimental skin lesions from larvae of the bot fly Dermatobia hominis. Med. vet. Entomol., 15: 22-27, 2001.

22. PEREIRA, M.C.T. \& LEITE, A.C.R. - Eosinophil and mast cell expression in host skin during larval development of the human bot fly Dermatobia hominis. Parasite, 9: 333-339, 2002.

23. PIRES, F.A.; MOYA-BORJA, G.E.; BARREIRA, J.D.; PINHO, R.T. \& ALVES, C.R. - The main proteinases in Dermatobia hominis second and third instar larvae are serine-proteases. Vet. Parasit., 145: 326-331, 2007.

24. SABROSKY, C.W. - North American species of Cuterebra, the rabbit and rodent bot flies (Diptera: Cuterebridae). Thomas Say Foundation, 11: 1-240, 1986.

25. SCHOLL, P.J. - Biology and control of cattle grubs. Ann. Rev. Entomol., 38: 53-70, 1993.

26. SLANKY, F. - Insect/man associations: effects of Cuterebrid bot fly parasites on their hosts. Ann. Rev. Entomol., 52: 17-36, 2007.

27. TABOURET, G.; PREVOT, F.; BERGEAUD, J.P.; DORCHIES, P.H. \& JACQUIET, P. - Oestrus ovis (Diptera: Oestridae): sheep humoral immune response to purified excreted/secreted salivary gland $28 \mathrm{KDa}$ antigen complex from second and third instar larvae. Vet. Parasit., 101: 53-66, 2001.

28. TONG, N.T.; IMHOFF, J.M.; LECROISEY, A. \& KEIL, B. - Hypodermin A, a trypsinlike neutral proteinase from the insect Hypoderma lineatum. Biochim. Biophys. Acta, 658: 209-219, 1981.

Received: 3 February 2009

Accepted: 13 April 2009 